\title{
VENDOR AND PURCHASER-SECTION 34 (17) OF ALBERTA JUDICATURE ACT-WHETHER AGREEMENT MERGES IN TRANSFER SO THAT VENDOR MAY RECOVER ON PROMISSORY NOTE GIVEN BY PURCHASER-ROSS v. HAINES
}

The recent case of Ross v. Haines, ${ }^{1}$ in the Alberta Court of Appeal is one that should be of more than considerable interest to vendors and purchasers of land, as well as to the legal profession. It is the purpose of this comment to show that the decision in Ross v. Haines leaves considerable doubt as to what protection will be given purchasers of land under the provisions of Section 34 (17) of the Alberta Judicature Act. ${ }^{2}$

Section 34 (17) as amended provides in part as follows:

In an action brought upon a mortgage of land whether legal or equitable, or upon an agreement for the sale of land, the right of the mortgagee or vendor thereunder is restricted to the land to which the mortgage or agreement relates and to foreclosure of the mortgage or cancellation of the agreement for sale, as the case may be, and no action lies.

(a) on a covenant for payment contained in any such mortgage or agreement for sale,....

The essence of the protection afforded by this Section is that where a purchaser or mortgagor of land is in default of payment, the respective vendor or mortgagee is restricted in his remedy to the land. After receiving the proceeds of the sale of the land, the vendor or mortgagee cannot recover any deficiency in the purchase price by a personal action against the purchaser or mortgagor.

During the early history of this Section, the protection given by it to purchasers of land, was zealously enforced by the Alberta courts. ${ }^{3}$ In cases where the transaction was disguised for the purpose of circumventing the Section, courts readily looked through the form to the substance of the transaction. By applying the principle that one cannot do indirectly what one cannot do directly, any transaction which was in substance an action on the covenant to pay was held not maintainable.

As a result of two recent decisions in the Supreme Court of Canada ${ }^{4}$ the Alberta courts found it necessary to re-examine their position. The case of Ross v. Haines reflects this re-examination. It is submitted that the judgment of Johnson, J. A., with which Manning, J. A., and McDermid, J. A. concurred, signifies a new trend in adjudication in this area of the law.

The facts ofRoss v. Haines may be stated shortly. The appellants, under an agreement for sale, sold a half section of land to the respondent for the full price of $\$ 21,000.00$. The respondent paid a deposit of $\$ 500.00$ and later paid an additional $\$ 19,500.00$ in cash and gave a promissory note for the remaining $\$ 1,000.00$. At this point the appellants gave a transfer of the property, which was subsequently registered by the

1 (1966), 55 D.L.R. (2d) 511

2 R.S.A. 1955, c. 164. $[1936] 2$ W.W.R. 205 (Alta. C.A.). British American Oil Co. v.

Frang v. Rutherford, [1936] 2 W.W.R. 205 (Aita. C.A.)

4 Krook v. Yewchulk (1962), 39 W.W.R. (N.S.) 13 (S.C.C.) Edmonton Airport Hotel v. Credit Foncier, [1965] S.C.R. 441. 
respondent. The appellant brought an action on the promissory note and the respondent's sole defence was that the note was given to secure the balance owing under the agreement for sale. The respondent argued that in substance the appellant's action was on a covenant for payment, and that this was forbidden by Section 34 (17) of the Judicature Act.

At Trial this defence was upheld; however the Appellate Division allowed the appeal. In a written judgment, Johnston, J. A. held on the authority of Knight Sugar Co. Ltd. v. Alberta Railway and Irr. Co. ${ }^{\circ}$ that the agreement for sale was an executory contract that merged in the conveyance when the transfer of land was made to the respondent. Aside from a vendor's lien action, there was no longer an action upon the agreement for sale, since the agreement had merged in the transfer.

The Haines case broke new ground; it marked the first time that the doctrine of merger had been applied in order to separate the security given from the agreement for sale so that an action could be brought on the security. By so doing, the court was able to pronounce the action to be on the promissory note and not on the agreement for sale, since the agreement no longer existed.

It is respectfully submitted that this was an unwarranted extension of the doctrine of merger, or in the alternative that this was not a proper case for its application. ${ }^{\circ}$

Johnston, J. A., found authority in the Knight Sugari case of the application of merger. The writer agrees that the Knight Sugar decision is proper authority for the principles of merger applied in Ross v. Haines. However, it is suggested that the court in forming its decision in the Haines case did not consider the doctrine in the full context of the Knight Sugar decision, since the doctrine depends upon the intention of the parties.

Lord Russell of Killowen in the Knight Sugar case said:

All the provisions of the contract which the parties intend should be performed by the conveyance are merged in the conveyance, and all the rights of the purchaser in relation thereto are thereby satisfied. There may, no doubt, be provisions of the contract which from their nature or from the terms of the contract survive after completion. [Emphasis added] ${ }^{8}$

Lord Russell went on to satisfy himself that the necessary intention was present. He stated:

There can be no question in their Lordship's view that, ... the parties in the present case intended that the provisions of the sale agreement should be performed by the transfer and the subsequent certificate of title, and that accordingly, subject to a point next to be mentioned, the real contract as regards parcels is to be found not in the executory agreement but in the completed transaction.9

It is submitted that in the instant case the court failed to recognize this element of intention in determining whether there had been a merger; if they had considered it, they would not so readily have applied the doctrine.

5 [1938] 1 W.W.R. 234.

6 Re Forester Estate, [1941] 3 W.W.R. 449. The court, commenting on the doctrine of merger, suggested that the doctrine, at least in relation to mortgages, is confined to merger of estates in land. 7 Ante, n. 5, The Knight Sugar case approves the doctrine of merger as interpreted in

8 Ante, n.5., at 238 .

9 Ibid. 
Section 34 (4) of the Judicature Act $^{10}$ provides that equity is to prevail with regard to merger:

(4) There shall not be a merger by operation of law only of any estate the beneficial interest in which would not be deemed to be merged or extinguished in equity.

Cozens-Hardy, L. J. in Capital and Counties Bank Ltd. v. Rhodes ${ }^{11}$ explained the situation in equity:

The courts of Equity, on the other hand, in many cases treated the interest which merged at law as being still subsisting in equity. They had regard to the intention of the parties, and (in the absence of any direct evidence of intention, they presumed that merger was not intended, if it was to the interest of the party, or only consistent with the duty of the party, that merger should not take place.12

The question that arises is where to look for this intention?

The intention may be found in the facts and circumstances surrounding the transaction, or may be presumed if the resulting merger is for the benefit of the party paying. ${ }^{13}$ An application of this principle in the Haines case would not result in a finding of presumed intention of merger since merger clearly did not operate for the purchaser's benefit.

Moreover, the object of Section 34 (17) should not be overlooked. The section expressly states that in an action on an agreement for sale the vendor's or mortgagee's remedy is restricted to the land and no action will lie on a covenant to pay. The protection provided by the section is clearly intended to inure to the benefit of the purchaser. It would seem that something more than mere presumed intention is required to override this express statutory protection. In fact, a recent amendment to section 34 has provided strong indication that the legislature intended the purchaser to have this protection in all cases. The new subsection states:

Any waiver or release hereafter given of the rights, benefits or protection given by subsections (17) and (18) is against public policy and void. ${ }^{14}$

Any presumed intention to effect a merger in the Haines case appears to be negatived by contrary legislative intention as expressed in the statute.

Having demonstrated the lack of intention to cause a merger in the Haines case, it is submitted that there is authority in the Alberta case of Coal \& Coke v. Trelle $e^{15}$ for the proposition that both the preliminary contract and the subsequent deed continue to have an independant existence. There the parties executed an agreement for sale which contained a 'restrictive covenant.' The defendant had the transfer registered and the ensuing certificate of title contained a reference to the proviso in the transfer. The defendant claimed not to be bound by the restrictive covenant in the agreement. He maintained that the agreement became merged in the transfer, and that since the transfer had not been executed by him, the covenant therein was not binding upon him. Stuart, J. in his judgment said:

I do not think that this contention can be sustained. No doubt there are a number of authorities which lay down the principle that when a preliminary

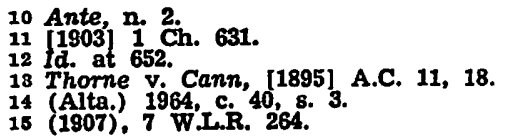


agreement has been made between two parties which contemplate the execution of a more formal deed containing the terms of the agreement in more extended form, and the covenants by which the parties are to be bound, in such case it is the final deed alone which must be looked to and that the preliminary agreement becomes merged in the deed; but I am of opinion that the present case is of quite a different nature ... I cannot see how it can be contended that it was ever contemplated by the parties that the transfer should supercede the agreement entirely. The parties were no doubt aware that a transfer under our registration system is not in form . . a deed inter partes such as existed in the case referred to by the defendant. It was, therefore, I think, the clear intention of the parties, that the preliminary contract ... should go on after the transfer had been executed ..." [Emphasis added]

This view of Stuart, J. is in agreement with that of Lord Russell in the Knight Sugar case. On these authorities, it is submitted that the Haines case was not a proper case for the application of the doctrine of merger.

However, so long as the Haines decision remains law and the Legislature wishes to continue to protect purchasers of land, it will be incumbent upon the Legislature to redraft Section 34 (17) to cover cases of merger.

It is suggested that this decision will have considerable effect upon the form of future land transactions. Vendors of land, now have some support for what are in effect deficiency judgments. These vendors, who once found it necessary to take large down payments on land sold by them because their only remedy in default of payment was foreclosure, can now sell their property at low down payments and take the balance in promissory notes. The magic is in the transfer of the property. Once conveyed, subsequent default in payment of notes would give the vendor all the normal rights of one suing in an action for debt. After judgment, his remedies would be seizure and sale of personal property owned by the purchaser and garnishee of the purchaser's wages, which are the very remedies that the legislature intended should not be available.

On the basis of the Haines decision, it is suggested that the application in this area of the maxim that one cannot do indirectly what one cannot do directly, has now been considerably narrowed. Here, the promissory note was in fact part of the consideration paid for the land. Consideration means of course the purchase price. The default on the promissory note must therefore be a default on the purchase price and consequently a default on the covenant to pay. It is submitted that in substance the action is clearly on the covenant to pay. However, in the Haines case, the court did not have to deal with this problem, because it found that merger had put an end to the agreement.

Section 34 (17) stipulates that there must be an action on an agreement for sale; then an action on the covenant contained therein is prohibited. Applying the doctrine of merger, this section can be readily circumvented by transferring the title to the purchaser, thus extinguishing the agreement and leaving the note, so to speak, 'high and dry.' The vendor then has both the vendor's lien (so long as the title subsists in the purchaser) ${ }^{17}$ and the right to a personal judgment against the purchaser in debt action. 
It is worth noting that at the time the Knight Sugar case was decided, the Judicature Act provided that any property of a defaulting purchaser was subject to sale in order to realize a deficiency, after the land in question had been sold. ${ }^{18}$ The court did not have to decide whether the intention as expressed by the Judicature Act negatived the application of merger. Subsequent to the Knight Sugar decision, the Act was amended, restricting the mortgagee's and vendor's rights to the land and prohibiting an action on the covenant. ${ }^{19}$ It is suggested therefore that the Knight Sugar case should be followed only after due consideration of this change in the statute.

The basis of this new approach to the interpretation of Section 34 (17) was laid down in the two recent Supreme Court of Canada decisions mentioned earlier. ${ }^{20}$

The Krook case dealt with a sale of a hotel, in which there was a land mortgage and a chattel mortgage on the chattels in the hotel. The Supreme Court of Canada held that the vendor could enforce both mortgages, without violating Section 34 (17). This was not an attempt to recover a deficiency, but rather, was a foreclosure of the mortgages.

In Credit Foncier v. Edmonton Airport Hotel, again there were chattel and land mortgages, plus a personal guarantee by the co-defendant Superstein. On the basis of the Krook case there was no difficulty in enforcing the two mortgages. However, with regard to the guarantee, the court considered Superstein a third party to the transaction against whom enforcement of the guarantee was not in fact enforcement of the mortgagor's personal covenant.

The principle applied in these two important cases was succinctly stated by Martland, $J$. in the Krook case:

I do not find anything in this provision [Section 34 (17)] which forbids a debtor to give security for a debt on property in addition to a mortgage on land or which forbids the creditor to enforce such security. ${ }^{21}$

However, this statement does not necessarily eliminate the maxim that indirect means will not avail, for he stated later in his judgment:

In my opinion the taking of the chattel mortgage in the present case was not an indirect method of attempting to enforce the personal covenant contained in the land mortgage, . The essence of the present transaction is that it consisted of a sale totality of assets $\ldots . .^{22}$

These two cases deal with the right to enforce the land and chattel mortgages. There is no guarantee that the proceeds derived from foreclosure proceedings will be sufficient to meet the amount owing. The cases do not go further to suggest that an action could be maintained for a deficiency.

The Haines case differs on its facts from the two above cases. In those cases the action was brought to realize on chattel mortgages of property which was sold with the land. The action in the Haines case is not one to realize on additional security, but is rather an action to enforce a personal promise to pay made by the purchaser. The latter

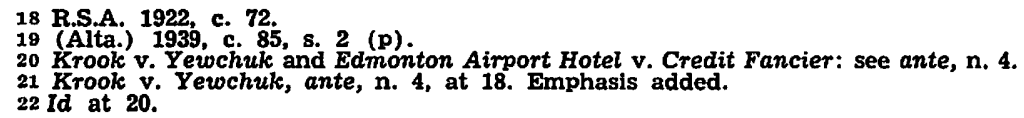


case extends the law considerably in this area. The mortgage cases would permit only foreclosure on the mortgages in question. The Haines decision permits a vendor to obtain judgment and execution on the promissory note, which amounts to recovery of the unpaid deficiency.

The cases dealing with mortgages of land have restricted former interpretations given to Section 34 (17) by introducing the concept of enforcing "additional securities." Similarily, with agreements for sale, the protection afforded by Section 34 (17) has been even more abridged by the "magic of merger" doctrine as adopted by the Alberta Court of Appeal in Ross v. Haines.

Ford, J. A. in Martin v. Strange, ${ }^{23}$ referring to Section 34 (17), said:

... whatever is the proper view as to their effect, they are provisions passed for the benefit alone of mortgagors and purchasers of land. 24

If this sentiment is shared by the Provincial legislators, and the need for protecting purchasers of land is real, then it is necessary that the legislature act quickly to repair the gap opened in Section 34 (17) rather than wait until a "harsh case" makes government action imperative.

A. R. KRUSHFLNICKI*

28 Martin v. Strange, [1943] 4 D.L.R. 367.

24 Id. at 369 .

B.A.. LL.B. (Alta.) of the 1966 graduating class. 